\title{
HLA-DRB1 wt Allele
}

National Cancer Institute

\section{Source}

National Cancer Institute. HLA-DRB1 wt Allele. NCI Thesaurus. Code C52341.

Human HLA-DRB1 wild-type allele is located in the vicinity of 6 p21.3 and is approximately $11 \mathrm{~kb}$ in length. This allele, which encodes HLA class II histocompatibility antigen, DRB1-4 beta chain protein, plays a role in the mediation of antigen presentation. 